\title{
Dysentery as the only presentation of COVID-19 in a child: a case report
}

\author{
Marjan Tariverdi ${ }^{1}$, Nazanin Farahbakhsh ${ }^{2 *}$, Hamed Gouklani ${ }^{3}$, Fatemeh Khosravifar ${ }^{4}$ \\ and Mohammad Tamaddondar ${ }^{5}$
}

\begin{abstract}
Introduction: The coronavirus disease 2019 (COVID-19) pandemic has caused irreparable damage to society, and the damage continues. Pediatricians are confronted with COVID-19 in a variety of presentations, which may lead to delayed diagnosis and treatment. Early diagnosis of the disease plays an important role in preventing transmission of the virus in the community.

Case presentation: Here we report a 27-month-old previously healthy Iranian female child who presented with fever and bloody diarrhea, diagnosed with COVID-19 based on contact history, exclusion of enteric bacterial pathogens and parasites, and positive stool and nasopharyngeal severe acute respiratory syndrome coronavirus 2 (SARS$\mathrm{CoV}-2$ ) reverse transcriptase polymerase chain reaction (RT-PCR) tests. The patient had viral shedding for more than a month.

Conclusions: The pediatric population usually does not present with typical clinical features of COVID-19, which are respiratory involvement. Dysentery may be the only presentation of this disease, and long-term isolation should be considered, as the viral shedding may last for more than a month.
\end{abstract}

Keywords: COVID-19, Dysentery, SARS-CoV-2, Pediatric, Case report

\section{Introduction}

In December 2019, an epidemic of what would later become known as coronavirus disease 2019 (COVID-19), caused by severe acute respiratory syndrome coronavirus 2 (SARS-CoV-2), began with the report of a pneumonia with an unknown cause from Wuhan, Hubei Province, China. The pathogen was identified as a novel coronavirus in early January, and finally on January 30, 2020, the World Health Organization (WHO) declared the novel coronavirus a public health emergency of international concern [1].

As COVID-19 is a novel disease, there is still a large information gap in its clinical presentations in the pediatric population. Consequently, reporting every new manifestation of this disease can help physicians in timely diagnosis and treatment of similar cases. Despite the preliminary data on the presentation of COVID-19, which was focused on respiratory symptoms, as the pandemic persists and more cases are diagnosed, other clinical features of COVID-19 have been identified [1]. Gastrointestinal (GI) symptoms of COVID-19 including diarrhea, nausea, vomiting, abdominal pain, and GI bleeding have been mentioned in previous studies [2-4], but to date no dysentery with COVID-19 in the pediatric population has been reported. We aimed to describe a 27 -month-old female with COVID-19 who presented with dysentery as the only presentation of this disease.

*Correspondence: nazanin26farahbakhsh@yahoo.com

2 Department of Pediatric Pulmonology, Mofid Children's Hospital, Shahid

Beheshti University of Medical Sciences, Tehran, Iran

Full list of author information is available at the end of the article

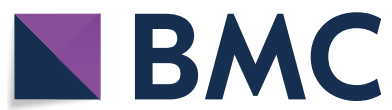
permits use, sharing, adaptation, distribution and reproduction in any medium or format, as long as you give appropriate credit to the original author(s) and the source, provide a link to the Creative Commons licence, and indicate if changes were made. The images or other third party material in this article are included in the article's Creative Commons licence, unless indicated otherwise in a credit line to the material. If material is not included in the article's Creative Commons licence and your intended use is not permitted by statutory regulation or exceeds the permitted use, you will need to obtain permission directly from the copyright holder. To view a copy of this licence, visit http://creativecommons.org/licenses/by/4.0/. The Creative Commons Public Domain Dedication waiver (http://creativeco mmons.org/publicdomain/zero/1.0/) applies to the data made available in this article, unless otherwise stated in a credit line to the data. 


\section{Case presentation}

A 27-month-old Iranian female child was brought to our center due to fever, vomiting, and loose stool for 2 days prior to admission. The patient had been seen in an outpatient clinic, but as conservative care was not effective, she was admitted to the infectious ward. She had no significant past medical history or any comorbid medical conditions. There was no recent travel history, and no members of her family had the same symptoms except for the grandfather, who had experienced fever and malaise for a week. On admission, the patient's temperature was $39{ }^{\circ} \mathrm{C}$, and she had sunken eyes, dry mucosa, and fair skin turgor. Laboratory data results were as follows: stool exam, 10 white blood cells (WBCs)/highpower field (HPF); 10 red blood cells (RBCs)/HPF; many pus cells. Stool culture was negative for enteric bacterial pathogens and parasites. Other laboratory results included C-reactive protein (CRP) $29 \mathrm{mg} / \mathrm{l}$, complete blood count (CBC); WBC 3400/ $\mu$ l, 27\% lymphocyte and $52 \%$ neutrophil. According to the guideline of this center, intravenous hydration and ceftriaxone were administered as approved empirical therapy in children with dysentery. No appropriate clinical or laboratory response was observed. On the second day of admission, the patient developed abdominal cramps following bloody diarrhea and an increase in CRP level to $69 \mathrm{mg} / \mathrm{l}$. Meanwhile, we were informed that the grandfather had subsequently tested positive for SARS-CoV-2 by reverse transcriptase polymerase chain reaction (RT-PCR) test, and the patient had close contact with him. We ordered a chest X-ray (CXR) and chest computed tomography (CT), and pharyngeal and stool samples were tested for SARSCoV-2 by RT-PCR. Both CXR and CT scans were normal, while surprisingly the results of both SARS-CoV-2 tests were positive. Thus, the patient was isolated. As she had no respiratory symptoms, according to our national guideline [5], we decided to continue with conservative treatment.

On day 4 of admission, she had no vomiting and had good oral tolerance. Fever and bloody diarrhea had stopped. On day 7, SARS-CoV-2 tests for nasopharyngeal and stool samples were still positive. The patient was discharged after the parents were educated on how to continue respiratory and gastrointestinal isolation. She was tested every week for SARS-CoV-2 in nasopharyngeal and stool samples. Both test results were negative 32 days after the onset of symptoms.

\section{Discussion and conclusions}

The novel coronavirus SARS-CoV-2 is a new member of the family Coronaviridae, genus Betacoronavirus, which was first described in a series of patients presenting with pneumonia in China. Similar to lessons learned from severe acute respiratory syndrome (SARS), although at a lower frequency, SARS-CoV-2 has tropism to the GI tract $[3,6]$. The angiotensinconverting enzyme 2 (ACE2) receptor is believed to be responsible for the entrance of SARS-CoV-2 into the cells, and it is abundantly expressed in the GI tract epithelium. This may account for the GI symptoms of COVID-19 patients and the potential fecal-oral transmission of the disease [7, 8]. Indeed, there have been some pediatric cases with a confirmed diagnosis of COVID-19 who did not show respiratory symptoms as their initial and main presentations. They may initially be considered common pediatric illnesses other than COVID-19, such as febrile seizure or gastroenteritis, and lead to the spread of the disease in the community and among medical staff [9].

GI symptoms have been reported in children with COVID-19 either with or without respiratory symptoms. The most common GI symptoms were anorexia, vomiting, and diarrhea $[2,4,10]$. A few cases of GI bleeding have also been reported [2]. Although pediatric cases of COVID-19 with GI symptoms including abdominal pain and GI bleeding, and especially diarrhea, have been reported, the index case presented with dysentery with no clinical or radiological respiratory involvement, and to date, no similar case of dysentery as the only presentation in children with COVID-19 has been reported. Alternatively, different infectious etiologies might have caused dysentery and fever. However, no enteric bacterial pathogens or parasites other than SARS-CoV-2 were recovered from stool analysis and culture. The possibility of pseudomembranous colitis induced by the introduction of ceftriaxone was weak, as the patient had clinical and laboratory evidence of colitis prior to the administration of ceftriaxone.

Some physicians have attributed the GI symptoms to the hypoxia, as cell necrosis from tissue hypoxia may cause gastrointestinal mucosal cell damage, resulting in ulceration and hemorrhage [2]. However, our patient had no hypoxia and was not critically ill, and this may show that dysentery was the primary result of COVID-19 and that it can be considered as a new feature of this virus.

No respiratory symptoms were seen and the patient was not in critical condition; therefore, we did not use any antiviral treatment or hydroxychloroquine, as not only has the efficacy of these drugs on COVID-19 not yet been proven, but they may have significant adverse effects. We also followed the patient until both nasopharyngeal and stool tests were negative to determine the duration of viral shedding and the required isolation period. In many cases of COVID-19, viral shedding can continue beyond 14 days with positive RT-PCR tests; nevertheless, the follow-up of every patient for long 
periods of time in routine practice is not possible. On the other hand, the positive RT-PCR tests beyond the resolution of symptoms may not necessarily indicate the possibility of disease transmission, as in some cases of COVID-19, the high viral load at admission can account for this finding.

In conclusion, pediatric patients with COVID-19 usually do not present with typical clinical features of the infection, which is respiratory involvement. Dysentery may be the only presentation of this disease, and longterm isolation should be considered, as the viral shedding may last for more than a month. We aimed to increase awareness among pediatricians and other clinicians in considering COVID-19 as a possible etiology for abdominal pain and dysentery in children.

\section{Abbreviations}

ACE2: Angiotensin-converting enzyme 2; COVID-19: Coronavirus disease 2019; CRP: C-reactive protein; CT: Computed tomography; CXR: Chest X-ray; Gl: Gastrointestinal; HPF: High-power field; RBC: Red blood cell; RT-PCR: Reverse transcriptase polymerase chain reaction; SARS-CoV-2: Severe acute respiratory syndrome coronavirus 2; WBC: White blood cell.

\section{Acknowledgements}

We sincerely appreciate the dedicated efforts of the personnel of Bandar Abbas Pediatric Hospital.

\section{Authors' contributions}

MT examined the patient and was a major contributor in writing the manuscript. HG was consulted on the appropriate laboratory tests, collected the samples, and performed the tests. FK took a comprehensive history from the patient's parents. NF wrote the manuscript. MT revised the manuscript. All authors read and approved the final manuscript.

\section{Funding}

No funding was received.

\section{Availability of data and materials}

The data sets used during the current study are available from the corresponding author on reasonable request.

\section{Ethics approval and consent to participate}

The study received ethics approval from the Ethical Committee of Hormozgan University of Medical Sciences under the ethics code HUMS.REC.1399.303, and it complies with the statements of the Declaration of Helsinki.

\section{Consent for publication}

Written informed consent was obtained from the patient's legal guardian(s) for publication of this case report and any accompanying images. A copy of the written consent is available for review by the Editor-in-Chief of this journal.

\section{Competing interests}

The authors declare that they have no competing interests.

\section{Author details}

${ }^{1}$ Department of Pediatric, Clinical Research Development Center of Children Hospital, Hormozgan University of Medical Sciences, Bandar Abbas, Iran.

${ }^{2}$ Department of Pediatric Pulmonology, Mofid Children's Hospital, Shahid Beheshti University of Medical Sciences, Tehran, Iran. ${ }^{3}$ Infectious and Tropical Diseases Research Center, Hormozgan Health Institute, Hormozgan University of Medical Sciences, Bandar Abbas, Iran. ${ }^{4}$ Student Research Committee, Hormozgan University of Medical Sciences, Bandar Abbas, Iran. ${ }^{5}$ Department of Nephrology and Internal Medicine, Shahid Mohammadi Hospital, Hormozgan University of Medical Sciences, Bandar Abbas, Iran.

Received: 8 November 2020 Accepted: 8 January 2021

Published online: 08 February 2021

\section{References}

1. Cai X, Ma Y, Li S, Chen Y, Rong Z, Li W. Clinical characteristics of 5 COVID19 cases with non-respiratory symptoms as the first manifestation in children. Front Pediatrics. 2020;8:258.

2. Tian Y, Rong L, Nian W, He Y. Review article: gastrointestinal features in COVID-19 and the possibility of faecal transmission. Aliment Pharmacol Ther. 2020;51(9):843-51.

3. Cimolai N. Features of enteric disease from human coronaviruses: Implications for COVID-19. J Med Virol. 2020;92:1834-44.

4. Tullie L, Ford K, Bisharat M, Watson T, Thakkar H, Mullassery D, et al. Gastrointestinal features in children with COVID-19: an observation of varied presentation in eight children. Lancet Child Adolesc Health. 2020;4(7):e19-20

5. Karimi A, Rafiei Tabatabaei S, Rajabnejad M, Pourmoghaddas Z, Rahimi $\mathrm{H}$, Armin S, et al. An Algorithmic approach to diagnosis and treatment of coronavirus disease 2019 (COVID-19) in Children: Iranian Expert's Consensus Statement. Arch Pediatr Infect Dis. 2020;8(2):e102400

6. Wong SH, Lui RN, Sung JJ. Covid-19 and the digestive system. J Gastroenterol Hepatol. 2020;35(5):744-8.

7. Xiao F, Tang M, Zheng X, Liu Y, Li X, Shan H. Evidence for gastrointestinal infection of SARS-CoV-2. Gastroenterology. 2020;158(6):1831-3.

8. Gu J, Han B, Wang J. COVID-19: gastrointestinal manifestations and potential fecal-oral transmission. Gastroenterology. 2020;158(6):1518-9.

9. Rezaei N. COVID-19 affects healthy pediatricians more than pediatric patients. Infect Control Hosp Epidemiol. 2020. https://doi.org/10.1017/ ice.2020.139.

10. Liu W, Zhang Q, Chen J, Xiang R, Song H, Shu S, et al. Detection of Covid19 in children in early January 2020 in Wuhan, China. N Engl J Med. 2020:382(14):1370-1.

\section{Publisher's Note}

Springer Nature remains neutral with regard to jurisdictional claims in published maps and institutional affiliations.

Ready to submit your research? Choose BMC and benefit from:

- fast, convenient online submission

- thorough peer review by experienced researchers in your field

- rapid publication on acceptance

- support for research data, including large and complex data types

- gold Open Access which fosters wider collaboration and increased citations

- maximum visibility for your research: over 100M website views per year

At $\mathrm{BMC}$, research is always in progress.

Learn more biomedcentral.com/submissions 